\title{
Work-Family Conflict Influences on Female's Career Development through Career Expectation
}

\author{
Wei Wang', Taejun $\mathrm{Cho}^{2}$ \\ ${ }^{1}$ Business School, Lin Yi University, Lin Yi, China \\ ${ }^{2}$ Department of Business Administration, Suwon University, Suwon, South Korea \\ Email: lyww772@126.com
}

Received August 15, 2013; revised September 15, 2013; accepted September 24, 2013

Copyright (C) 2013 Wei Wang, Taejun Cho. This is an open access article distributed under the Creative Commons Attribution License, which permits unrestricted use, distribution, and reproduction in any medium, provided the original work is properly cited.

\begin{abstract}
Nowadays, women are still underrepresented in the higher positions in most organizations. Some crucial questions are whether family responsibilities affect female career development and career expectation influences the relationship between work and family conflict and career development of women or not. Through surveying the female teachers in Lin Yi University and Shandong Medical College, this article wants to know the correct relationship among work and family conflict, career expectations and career developments for women.
\end{abstract}

Keywords: Work-Family Conflict; Career Expectation; Career Development

\section{Introduction}

Since the advent of the Women's Movement, women have made enormous strides toward equal opportunity in the workplace. Gender equality has become a basic policy in mainland China since 1995 [1]. Moreover, legislative changes now prohibit sex discrimination that has disparate impact on women actionable. In recent years, women have begun to crack the glass ceiling and gain entry into the upper levels of organizational power [1,2]. However, there are much fewer women employees in top manager positions than men fellows in China [3]. Women are still significantly underrepresented at the top levels of organizations [4].

Family responsibilities are one important factor influencing the amount of time and energy that individuals are able and willing to devote to work [5]. The demands of family have been shown to reduce women's personal resources of time, energy, and commitment available for work [6]. Heidi and Ellen [7] noted that the effects of gender on career expectation were often mediated by personal and environmental variables such as perceived support for combining work and family. Family responsibility has an adverse effect on work effort, particularly for women. Relatively low work effort will, in turn, limit opportunities for positive performance outcomes, such as merit increases and promotions [8].

There has been extensive research in western countries, such as the UK and the USA, demonstrating the exis- tence of work-family conflict and its adverse effects on women, both at work and home; see, for example, the work by [5,9-12]. However, much of this research is concerned with linking work-family conflict with life satisfaction, job satisfaction and work and home stressors of various kinds. Very little attention is paid in these studies to the differing of work-family conflict on women career expectation to career development. Since women in East Asia are still failing to reach higher organizational levels despite their increasing participation in the formal employment sector, we argue that there is a strong need for researching the relationship between work-family conflict and career development through career expectation for female. How the family and work conflict influences the career development of women, and how the career expectations mediate the relationships between the family and work conflict and career development of women are surveyed through 100 teachers in the Lin Yi University and Shandong Medical College, so that we can better understand and progress female career development. On the one hand, break down the traditional mode of men earning money outside while women just do the housework, lightening the burden that women have in the family, to give women a larger stage to show their potential. On the other hand, change the stereotyped image for roles of gender as that in America and clear up the man made segregation in the career development path for women, helping them to go further in the hotel Industry [3]. The model for this paper is Figure 1. 


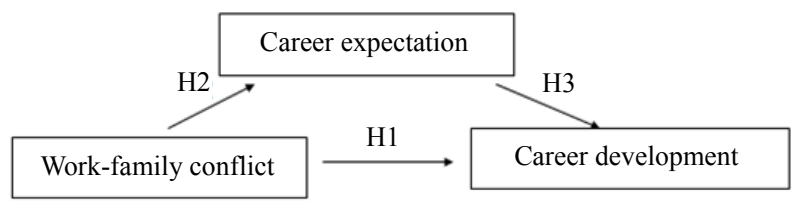

Figure 1. Proposed research framework.

\section{Theoretical Background and Literature Review}

\subsection{Work-Family Conflict and Career Development}

Work and family are important domains for most people. Researchers have focused on the interface between work and family by emphasizing the negative spillover between work and family domains. That is, when demands in one domain (i.e., work or family) limit one's ability to complete required duties in the other [13]. Since family responsibilities are the main reason mentioned for this interest in reducing actual working hours, therefore, family responsibilities and the wish or need for other working time arrangements reduce the perceived job alternatives [5]. Gender plays an important role for the work related effects of family responsibilities. Gendered roles affect the conditions and consequences of the work-family conflict [14]. Although we have entered new century for more than ten years, women still remain primarily responsible for homemaking and child-rearing responsibilities $[5,15]$. Less change has occurred in household responsibilities, where women still do more household work than men, even when employed [16,17].

Career development is described as the interactive progression of internal career identity formation and the growth of external career significance [18]. It is day-today micro-development, taking shape in the gradual strengthening, weakening, and change of certain roles. In adaptational and job crafting processes, and also in job changes, the real inherent career development is in the roles that people take on, more than in higher salaries or loftier job titles [18]. It also is seen as an interactive progression of positions and roles acquired, without per se representing progress as improvement [18]. Because family responsibilities are one important factor influencing the amount of time and energy that individuals are able and willing to devote to work [5]. Resources such as time, attention, and energy are finite, and those expended in one domain are unavailable for other domains. This constraint yields a negative direct relationship between family and work resources available for the other domain $[5,13]$. With fewer resources to invest at work, women's performance may suffer and in turn their ability to earn promotions and financial rewards $[6,9,10]$. Therefore it is not surprising that women tend to experience more workfamily conflicts [16], so family responsibilities have been considered in the context of women's career progression [1].

In China, the conflict between family and work is the most important obstacle faced by women in their career development [3]. Now dual-earner households are supplying more working hours to the labor market than ever before [5]. Furthermore, due to childbirth and the fact that women still carry the main responsibility for childcare and work in the home, their careers become more diverse, with temporary interruptions for maternal leave and periods of part-time work. In spite of these heavy career demands, and the increased participation of men in child care, women still do more of the child care and domestic work at home. Although employed married women spend less time on housework and childcare than non-employed women, they devote considerably more time to home and family in fulfilling their family role responsibilities than men [5]. As a result, many women professionals and managers carry a heavier work burden than most men, a "triple burden" of home, career and an often sexist workplace [11]. With the effects of gender and career identity salience controlled, a high level of family responsibility will be associated with relatively low work effort. With work effort controlled, the negative effect of family responsibilities on merit increases will be stronger for women than for men [8], so marriage and family have affected many women graduates' work decisions and career outcomes in complex ways [16]. With fewer resources to invest at work, women's performance may suffer and in turn their ability to earn promotions and financial rewards. In contrast, the personal stabilization and support that men have been shown to gain from the family may allow them to commit even more resources to work [6], so we can hypothesize,

H 1: The work-family conflict lower females career development.

\subsection{Work-Family Conflict Influences Career Development through Career Expectation}

According to social-cognitive theory, expectations play a causal role in shaping behavior, goals and ways of managing environmental demands in stressful situations [19], and are related to levels of subjective well-being [20]. Career expectations are the anticipatory psychological contract [20]. The anticipatory psychological contract is defined as individuals' pre employment beliefs about their future employment, including promises they want to make to their future employers and inducements they expect to receive in return [20]. In this study, we focus on Millennials' expectations about employer inducements because a breach of these expectations can have a detrimental effect on a number of outcomes, such as job satisfaction, commitment, job performance, and intention to 
stay $[22,25]$.

Since the internal dynamic of career motives and goals meets continually with the external dynamic of environmental influences. From early on in life, the family, peer groups, schools, clubs, and communities offer challenges and opportunities to commit, by the facts of life and through expectancies regarding the person's career [18]. Environmental influences remain important for careers over the life span, albeit differently for some groups, for instance, according to gender [18]. Researchers have argued that work-family conflict may have a significant impact on how individuals view their career outcomes [5]. In this respect, the gender differences in career outcomes may be explained by the fact that women no longer aspire or desire to be engulfed in work environments and arrangements that allow little control over work hours. Their career changes and employment decisions, predominantly guided by the demands of family care, can be understood through multiple perspectives [16].

Accordingly, socially accepted role-behaviors are still likely to affect young women's career expectations [11]. Many women have made career changes to accommodate their families. In this respect, the gender differences in career outcomes may be explained by the fact that women no longer aspire or desire to be engulfed in work environments and arrangements that allow little control over work hours. Their career changes and employment decisions, predominantly guided by the demands of family care, can be understood through multiple perspectives [16]. They have done so by seeking work places that allow more family time or flexible work options. While some men have done so, the majority of the men who have made career changes did so to earn more money. Many women also shared their feelings about the difficulties they face as women working in male-dominated occupations. Some have chosen to work in female-dominated work places (such as public schools and non-profit organizations) for the same reason. This may explain part of the differences in men's and women's market outcomes [16]. Human capital theory predict that individuals' family responsibilities will have a direct, negative effect on work effort and an indirect effect on performance outcomes, mediated by work effort [8]. In this respect, the gender differences in career outcomes may be explained by the fact that women no longer aspire or desire to be engulfed in work environments and arrangements that allow little control over work hours. Their career changes and employment decisions, predominantly guided by the demands of family care, can be understood through multiple perspectives [16]. We hypothesize that:

H 2: The work-family conflict has negative effect on female career expectations.

\subsection{Career Expectation Influences Career Development}

In this study, we focus on Millennials' expectations about employer inducements because a breach of these expectations can have a detrimental effect on a number of outcomes, such as job satisfaction, commitment, job performance, and intention to stay $[21,22]$. The idea that expectations are an important determinant of outcome satisfaction has been suggested by numerous theoretical perspectives. Thus, someone with low outcome expectations may be more satisfied with a given outcome than someone else with higher expectations might be with the same outcome [22]. Career expectations, which are arguably associated with both the nature and extent of any investments in human capital, and these in turn, play a major role in determining actual career outcomes [21]. Discrimination against women in the labor market impinges on their occupational expectations. This creates a "self-fulfilling prophecy"-women accept the social reality and societal expectations of them and as a result reduce their expectation. They also accept discrimination in earnings and jobs [11]. Hence, many highly educated women, including professionals, regard themselves as secondary breadwinners and their earnings as a supplement to the family unit's income [11]. Major [24] stated that "one's perception of the value of an activity is more important in determining one's decision to engage in that activity, while one's self-concept of ability is more important in determining one's actual performance once involved in the activity" (p. 778). Task value, then, is the more crucial portion of the model to examine in terms of understanding women's intentions to pursue a particular career-related activity [1]. So some researchers proposed that individuals' performance, persistence, and choice of achievement tasks are most directly predicted by their expectancies for success on the tasks and the subjective value they attach to success on the tasks. Individuals' expectancies and values themselves are most directly determined by other achievement-related beliefs, including children's achievement goals and sense of competence. Individuals' interpretations of their previous performance and their perceptions of socializers' attitudes and expectations influence their achievement-related beliefs [10].

Investigating perceived influence on career expectations is important because such perceptions are likely to influence behavior. For example a student who perceives luck to be an important influence on his or her career choice might be less likely to take career exploration and planning seriously [7]. Existing research also assumes that since management requires at able to progress in management simply because they do not have the desire to hold managerial positions [10]. In line with this theory, 
an individual's decision to invest in human capital (in the form of education and market training) can be understood via the cost-and-benefit or return-to-investment analysis, whereby the costs comprise of forgone earnings and direct costs, while benefits is measured in higher future earnings. Hence, an individual would only invest in as much human capital as $\mathrm{s} / \mathrm{he}$ thinks makes sense in accordance to his/her career expectations [16]. Consistent with earlier research $[8,19]$, these study show that expectations of success play a role in the career pursuits of women. Human capital theory suggests that women invest less in education and on-the-job training since they do not expect to engage as intensely as men do in the labor force; they also "choose" less demanding jobs because of family responsibilities, all of which results in their receiving lower pay relative to men [23].

Specifically, it has been suggested that women have lower pay expectations than men, hence their tendency to be equally as satisfied as men with lower pay or more satisfied than men with equivalent pay [24]. The important role of pay expectation in wage outcome is illustrated in a study using a job-simulation design conducted by Major et al. [24]. They found that applicants who communicated lower pay expectations were offered less pay than identically qualified applicants who communicated higher pay expectations. In light of empirical evidence of women's lower pay expectations, these findings suggest that women who expect less pay than men are likely to be offered less pay than their equally qualified male counterparts. Pay expectation appears to be an important factor in the quest to explain the gender wage gap [25]. It is apparent that gender has a very large effect upon occupational expectations. There are also distinct differences in terms of the magnitude of the association between education and career expectations across genders [26].

H3: Career expectations have negative influence on female career development.

\section{Methods}

Participants were 92 female teachers in Lin Yi University and Shandong Medical College. 100 questionnaires were distributed among teachers in Lin Yi University and Shandong Medical College. The sample size was arrived at using Krejcie and Morgan (1970) sample size determination criteria. Each questionnaire set was in an open envelope that also contained a letter from the researchers on university stationary requesting participation and assuring anonymity to respondents. We excluded participants who did not respond to all questionnaire items or for whom there was a suspicion of random response such as use of the identical answer throughout. A total of 92 respondents met these inclusion criteria.

\section{Results}

In the analyses, we controlled for several other known predictors of career development, age, marital status, educational attainment, and years of children (Table 1).

To measure work-family conflict, we used the scale developed by Carlson et al. [14]. The scale consists of nine items and measures work-family conflict, Sample items are: "My work keeps me from my family activities more than I would like", "I have to miss work activities due to the amount of time I must spend on family responsibilities", Items were scored on a 5-point rating scale ranging from 1 , "totally disagree", to 5 , "totally agree". Cronbach's $\alpha$ for female work-family interference was 0.80 in Table 2.

To measure career expectation, we used the scale developed by Carole (1998). The scale consists of 4 items and measures career expectation, for example "competition". Items were scored on a 5-point rating scale ranging from 1, "totally unimportant", to 5 , "totally important". Cronbach's $\alpha$ for female career expectation was 0.87 in Table 2.

Career development was operationalized as six items with 5-point response scales by Stephen (2012), for example (1) How satisfied are you with your career progress over the past 3 years? $(1=$ not satisfied; $3=$ moderately satisfied; $5=$ very satisfied). Cronbach's $\alpha$ for female career development was 0.89 in Table 2.

The items were refined and purified to obtain the reliable scale. For this purpose corrected item-to-total correlation and Cronbach's $\alpha$ statistics were used. Item and reliability analysis was performed to retain and delete scale items for the purpose of developing a reliable scale. Corrected item-to-total correlations and Cronbach's $\alpha$ statistics were employed to conduct this type of analysis;

Table 1. Respondents' Characteristics.

\begin{tabular}{ccc}
\hline Variable & \multicolumn{2}{c}{ Female } \\
\hline Age & Frequency & Percentage (\%) \\
\hline $25-35$ & 36 & 39.1 \\
$36-45$ & 40 & 43.7 \\
above 45 & 16 & 17.2 \\
Marital Status & & \\
Single & 25 & 27.2 \\
Married & 50 & 54.3 \\
Other & 17 & 18.5 \\
Years of children & & \\
less 6 years old & 30 & 32.6 \\
6 - 18 years old & 37 & 42.2 \\
above 19 years old & 25 & 27.2 \\
\hline
\end{tabular}


Table 2. Factor analysis results of model.

\begin{tabular}{|c|c|c|c|}
\hline \multirow{3}{*}{ Code } & \multicolumn{3}{|c|}{ Components } \\
\hline & Work-family & Career & Career \\
\hline & Conflict & Expectation & Development \\
\hline a1 & 0.99 & & \\
\hline $\mathrm{a} 2$ & 0.95 & & \\
\hline a3 & 0.96 & & \\
\hline a4 & 0.96 & & \\
\hline a5 & 0.98 & & \\
\hline b1 & & 0.98 & \\
\hline b2 & & 0.99 & \\
\hline b3 & & 0.91 & \\
\hline $\mathrm{c} 1$ & & & 0.90 \\
\hline $\mathrm{c} 2$ & & & 0.87 \\
\hline $\mathrm{c} 3$ & & & 0.69 \\
\hline $\mathrm{c} 4$ & & & 0.86 \\
\hline $\mathrm{c} 5$ & & & 0.88 \\
\hline $\mathrm{c} 6$ & & & 0.84 \\
\hline \multicolumn{4}{|l|}{ Scale } \\
\hline Reliability & 0.80 & 0.87 & 0.89 \\
\hline
\end{tabular}

Kaiser-Meyer-Olkin Measure of Sampling Adequacy $=0.867$; Bartlett's Test of Sphericity: Chi-Square $=103.7 ; \mathrm{DF}=74 ;$ Sig. $=0.00$. to know the extent to which any one item is correlated with the remaining items in a set of items under consideration, see Table 3.

In the Table 4, all of which had been declared in the hypotheses. Based on one-tailed tests, female work family conflict for 5 items (M4.41, SD0.649; M4.40, SD0.664, M4.37, SD0.691; M4.42, SD0.650; M4.41, SD0.649) indicate women suffer high work-family conflict. It supports H1. Career expectation for 3 items (M2.22, SD0.739; MD2.21, SD0.749; M2.17, SD0.779) indicate women have lower career expectation. It supports H2. Career development for 6 items (M3.99, SD0.883; M4.65, SD0.543; M4.0, SD0.798; M4.34, SD0.952; M2.95, SD0.882; M2.99, SD0.896) indicate women have lower career development at rank and salary but they have high career satisfaction. It supports $\mathrm{H} 3$.

Through the data of Table 4 we also can see the rank and salary (M2.95, SD0.882; M2.99, SD0.896) lower than job satisfaction (M3.99, SD0.883; M4.65, SD0.543; M4.0, SD0.798; M4.34, SD0.952). So we can get the findings that female lower career expectation cause lower rank and salary. But the lower career expectation makes women get satisfaction easily, so they have high job satisfaction.

The effect estimates for structural model are shown in Table 5. The total effect estimate is 0.683 for career expectation and career development. The fit measures are RMSEA $=0.05, \mathrm{NFI}=0.944, \mathrm{RFI}=0.921, \mathrm{CFI}=0.982$, $\mathrm{TLI}=0.974$ in Table 5 . The detailed results of analysis are shown in Tables $\mathbf{4}$ and $\mathbf{5}$ these values are significant to prove the hypotheses $\mathrm{H} 1, \mathrm{H} 2$ and $\mathrm{H} 3$.

Table 3. Corrected item-to-total correlation, alpha and Scale Variance for items of female career development.

\begin{tabular}{|c|c|c|c|c|c|}
\hline Code & Items & $\begin{array}{l}\text { Scale Mean if } \\
\text { Item Deleted }\end{array}$ & $\begin{array}{l}\text { Scale Variance if } \\
\text { Item Deleted }\end{array}$ & $\begin{array}{l}\text { Corrected Item-Total } \\
\text { Correlation }\end{array}$ & $\begin{array}{c}\text { Communalities } \\
\text { Extraction }\end{array}$ \\
\hline a1 & Due to family responsibilities miss work activities. & 47.12 & 31.645 & 0.480 & 0.979 \\
\hline a2 & The time for my family responsibilities influence work. & 47.13 & 31.192 & 0.531 & 0.934 \\
\hline a3 & Family responsibilities stress influence work. & 47.16 & 31.479 & 0.466 & 0.946 \\
\hline $\mathrm{a} 4$ & Tension and anxiety from my family life weaken job ability. & 47.11 & 31.658 & 0.477 & 0.943 \\
\hline a5 & Effective behavior at home is counterproductive at work. & 47.12 & 31.337 & 0.525 & 0.969 \\
\hline b1 & Competition & 49.32 & 34.350 & 0.078 & 0.961 \\
\hline b2 & Freedom & 49.33 & 34.618 & 0.044 & 0.967 \\
\hline b3 & Expertise & 49.36 & 34.386 & 0.063 & 0.913 \\
\hline $\mathrm{c} 1$ & career success satisfaction & 47.54 & 28.339 & 0.686 & 0.842 \\
\hline c2 & salary progression satisfaction & 46.88 & 31.623 & 0.598 & 0.573 \\
\hline c3 & career progress satisfaction & 47.53 & 29.702 & 0.601 & 0.820 \\
\hline $\mathrm{c} 4$ & Total job satisfaction & 47.20 & 27.698 & 0.695 & 0.784 \\
\hline $\mathrm{c} 5$ & Rank & 48.59 & 28.465 & 0.673 & 0.797 \\
\hline c6 & salary & 48.54 & 28.449 & 0.661 & 0.774 \\
\hline
\end{tabular}


Table 4. Basic statistics and correlation matrix.

\begin{tabular}{|c|c|c|c|c|c|c|c|c|c|c|c|c|c|c|c|c|}
\hline Code & M & SD & & & & & & & rrelation & coefficie & & & & & & \\
\hline & & & a1 & $\mathrm{a} 2$ & a3 & $\mathrm{a} 4$ & a5 & b1 & b2 & b3 & c1 & c2 & c3 & $\mathrm{c} 4$ & $\mathrm{c} 5$ & c6 \\
\hline a1 & 4.41 & 0.649 & 1.000 & & & & & & & & & & & & & \\
\hline a2 & 4.40 & 0.664 & 0.937 & 1.000 & & & & & & & & & & & & \\
\hline a3 & 4.37 & 0.691 & 0.955 & 0.918 & 1.000 & & & & & & & & & & & \\
\hline $\mathrm{a} 4$ & 4.42 & 0.650 & 0.961 & 0.924 & 0.920 & 1.000 & & & & & & & & & & \\
\hline a5 & 4.41 & 0.649 & 0.974 & 0.937 & 0.955 & 0.935 & 1.000 & & & & & & & & & \\
\hline b1 & 2.22 & 0.739 & -0.281 & -0.292 & -0.310 & -0.286 & -0.258 & 1.000 & & & & & & & & \\
\hline b2 & 2.21 & 0.749 & -0.313 & -0.323 & -0.340 & -0.317 & -0.290 & 0.970 & 1.000 & & & & & & & \\
\hline b3 & 2.17 & 0.779 & -0.231 & -0.243 & -0.264 & -0.234 & -0.209 & 0.888 & 0.898 & 1.000 & & & & & & \\
\hline c1 & 3.99 & 0.883 & 0.219 & 0.289 & 0.241 & 0.238 & 0.276 & -0.097 & -0.113 & -0.125 & 1.000 & & & & & \\
\hline c2 & 4.65 & 0.543 & 0.225 & 0.240 & 0.200 & 0.235 & 0.256 & -0.001 & -0.038 & -0.037 & 0.656 & 1.000 & & & & \\
\hline c3 & 4.00 & 0.798 & 0.042 & 0.124 & 0.060 & 0.064 & 0.085 & -0.019 & -0.018 & -0.035 & 0.810 & 0.532 & 1.000 & & & \\
\hline c4 & 4.34 & 0.952 & 0.181 & 0.253 & 0.193 & 0.175 & 0.217 & 0.051 & 0.040 & 0.024 & 0.736 & 0.675 & 0.737 & 1.000 & & \\
\hline $\mathrm{c} 5$ & 2.95 & 0.882 & 0.174 & 0.282 & 0.196 & 0.194 & 0.213 & -0.032 & -0.049 & -0.050 & 0.775 & 0.648 & 0.765 & 0.703 & 1.000 & \\
\hline c6 & 2.99 & 0.896 & 0.121 & 0.211 & 0.149 & 0.121 & 0.159 & 0.070 & 0.036 & 0.003 & 0.764 & 0.489 & 0.784 & 0.752 & 0.751 & 1.000 \\
\hline
\end{tabular}

Table 5. Regression weights.

\begin{tabular}{cccccc}
\hline & Estimate & S.E. & C.R. & P \\
\hline $\begin{array}{c}\text { Career } \\
\text { expectation }\end{array}$ & $<-\begin{array}{c}\text { Work-family } \\
\text { conflict }\end{array}$ & -0.349 & & -3.082 & 0.002 \\
$\begin{array}{c}\text { Career } \\
\text { development } \\
\begin{array}{c}\text { Career } \\
\text { development }\end{array}\end{array}$ & $\begin{array}{c}\text { Work-family } \\
\text { conflict }\end{array}$ & 0.268 & 0.140 & 1.914 & 0.056 \\
$\begin{array}{c}\text { Career } \\
\text { expectation }\end{array}$ & 0.039 & 0.124 & 0.315 & 0.752 \\
\hline
\end{tabular}

Chi-square $=103.7, \mathrm{DF}=74, \mathrm{P}=0.000, \mathrm{RMSEA}=0.05, \mathrm{GFI}=0.982$, $\mathrm{AGFI}=0.80, \mathrm{NFI}=0.944, \mathrm{RFI}=0.921, \mathrm{TLI}=0.974, \mathrm{CFI}=0.982$. Model is Significant.

\section{Discussion, Limitations and Conclusions}

This paper aims to identify the items for work-family conflict, career expectation and career development for female. In Table 2, the work-family conflict has the loading ranging from 0.95 to 0.99 . All the loadings are significant. It is due to the fact that this variable is the dominating variable to prove the work-family conflict. For example, due to family responsibilities miss work activities (0.99), the time for my family responsibilities influence work (0.95), family responsibilities stress influence work (0.96), tension and anxiety from my family life weaken job ability (0.96), and effective behavior at home is counterproductive at work (0.98) also play significant role in work-family conflict. The work-family conflict presents three ways-time, strain and behavior. So the family responsibility has prominent influence on job time. Moreover family strain influences the energy on job. Effective behavior at home is not effective on job. The career expectation has also significant loading of all the variables - competition (0.98), freedom (0.99), and expertise (0.91). All the loadings are significant. The maximum loading for career expectation shows that this variable is the most dominating. It is due to the fact that most people expect their career through competition to get promotion in this competitive world. It is also needed to get freedom from job. These factors are important for career.

The career development also have significant loading career success satisfaction $(0.90)$, salary progression satisfaction (0.87), career progression satisfaction (0.69), rank (0.88) and salary $(0.84)$. All the loadings are significant.

Also, the results of the study are in consonance with the studies quoted in the literature review. However, despite the statistical sophistication of structural equation modeling, this study has the major limitations as few of the lot of top managements participated in the study.

The sample was not representative of the entire China. A larger more representative sample of individuals would have permitted more sophisticated analysis with larger subgroup sizes. Moreover, this study only mentioned work-family conflict and did not mention family-work conflict. In fact work-family conflict includes both directions of work-family conflict, i.e., WFC and FWC. In addition, future scholars might be able to use these findings to conduct research on similar topics using a nationally representative sample.

In the first half of the twentieth century, Chinese women were devalued and confined to the domestic sphere while Chinese men accepted the obligation to 
support their family financially. In spite of these social changes and some gender differences in men and women's external careers in China, the most consistent finding of this study is that women face high work-family conflict, influence their career expectation and hider career development. Based on these findings, organizational policy-making managers and career women can learn that women as well as men may be very desirable employees who are motivated to achieve. This study indicates that women and men are ready and eager to contribute to organizations that are willing to give them a chance and women are particularly motivated by situations that give them opportunities to learn.

\section{REFERENCES}

[1] L. A. Rudman and J. E. Phelan, "Backlash Effects for Disconfirming Gender Stereotypes in Organizations," Research in Organizational Behavior, Vol. 28, 2008, pp. 61-79.

[2] L. K. Stroh, C. L. Langlands and P. A. Simpson, "Shattering the Glass Ceiling in the New Millennium," In: M. S. Stockdale and F. J. Crosby (Eds.), The Psychology and Management of Workplace Diversity, Blackwell, Malden, 2004, pp. 147-167.

[3] Y. Yang, "Gender and Engineering Career Development of Hotel's Employees in China," Systems Engineering Procedia, Vol. 1, 2011, pp. 365-371. doi:10.1016/j.sepro.2011.08.055

[4] D. A. O'Neil, M. M. Hopkins and D. Bilimoria, "Women's Careers at the Start of the 21st Century: Patterns and Paradoxes," Journal of Business Ethics, Vol. 80, 2008, pp. 727-743.

[5] W. Mayrhofer, M. Meyer, M. Schiffinger and A. Schmidt, "The Influence of Family Responsibilities, Career Fields and Gender on Career Success," Journal of Managerial Psychology, Vol. 23, No. 3, 2008, pp. 292-323. doi:10.1108/02683940810861392

[6] C. Kirchmeyer, "The Different Effects of Family on Objective Career Success across Gender: A Test of Alternative Explanations," Journal of Vocational Behavior, Vol. 68, No. 2, 2006, pp. 323-346. doi:10.1016/j.jvb.2005.05.002

[7] H. K. Paa and E. H. McWhirter, "Perceived Influences on High School Students' Current Career Expectations," The Career Development Quarterly, Vol. 49, No. 1, 2000, p. 29.

[8] S. A. Lobel and L. St. Clair, "Effects of Family Responsibilities, Gender, and Career Identity Salience on Performance Outcomes," Academy of Management Journal, Vol. 35, No. 5, 1992, p. 1057.

[9] B. Orser and J. Leck, "Gender Influences on Career Success Outcomes," Gender in Management: An International Journal, Vol. 25, No. 5, 2010, pp. 386-407. doi: $10.1108 / 17542411011056877$

[10] H. Tlaiss and S. Kauser, "The Impact of Gender, Family, and Work on the Career Advancement of Lebanese Wo- men Managers," Gender in Management: An International Journal, Vol. 26, No. 1, 2011, pp. 8-36. doi:10.1108/17542411111109291

[11] J. Acker, "From Glass Ceiling to Inequality Regimes," Sociologie du Travail, Vol. 51, No. 2, 2009, pp. 199-217. doi:10.1016/j.soctra.2009.03.004

[12] N. Danziger and Y. Eden, "Gender-Related Differences in the Occupational Aspirations and Career-Style Preferences of Accounting Students," Career Development International, Vol. 12, No. 2, 2007, pp. 129-149. doi:10.1108/13620430710733622

[13] J. R. Edwards and N. P. Rothbard, "Mechanisms Linking Work and Family: Clarifying the Relationship between Work and Family Constructs," Academy of Management Review, Vol. 25, 2000, pp. 178-199.

[14] D. S. Carlson and K. M. Kacmar, "Work-Family Conflict in the Organization: Do Life Role Values Make a Difference?" Journal of Management, Vol. 26, No. 5, 2000, pp. 1031-1054.

[15] S. H. Osipow and L. F. Fitzgerald, "Theory of Career Development," A Pearson Education Company, Upper Saddle River, 1996.

[16] K. Mahitivanichcha, "Beyond Education and Market Access: Gender Differences in How Human Capital and Ability Translate into Market Outcomes," Ph.D. Dissertation, University of Texas, Austin, 2003.

[17] S. J. South and G. Spitze, "Housework in Marital and Nonmarital Households," American Sociological Review, Vol. 59, No. 3, 1994, pp. 327-347. doi: $10.2307 / 2095937$

[18] H. A. Hoekstra, "A Career Roles Model of Career Development," Journal of Vocational Behavior, Vol. 78, No. 2, 2010, pp. 159-173. doi:10.1016/j.jvb.2010.09.016

[19] A. Bandura, "Self-Efficacy: The Exercise of Control," Freeman \& Co, New York, 1997.

[20] A. De Vos, K. De Stobbeleir and A. Meganck, "The Relationship between Career-Related Antecedents and Graduates' Anticipatory Psychological Contracts," Journal of Business and Psychology, Vol. 24, No. 3, 2009, pp. 289298. doi:10.1007/s10869-009-9107-3

[21] S. De Hauw and A. De Vos, "Millennials' Career Perspective and Psychological Contract Expectations: Does the Recession Lead to Lowered Expectations?" Journal of Business and Psychology, Vol. 25, No. 2, 2010, pp. 293302. doi:10.1007/s10869-010-9162-9

[22] H. Zhao, S. J. Wayne, B. C. Glibkowski and J. Bravo, "The Impact of Psychological Contract Breach on WorkRelated Outcomes: A Meta-Analysis," Personnel Psychology, Vol. 60, No. 3, 2007, pp. 647-680. doi:10.1111/j.1744-6570.2007.00087.x

[23] G. Krantz, L. Berntsson and U. Lundberg, "Total Workload, Work Stress and Perceived Symptoms in Swedish Male and Female White-Collar Employees," European Journal of Public Health, Vol. 15, No. 2, 2005, pp. 209214. doi:10.1093/eurpub/cki079

[24] B. Major and E. Konar, "An Investigation of Sex Differences in Pay Expectations and Their Possible Causes," Academy of Management Journal, Vol. 27, No. 4, 1984, 
pp. 777-791. doi:10.2307/255878

[25] S. Alvin Leung, Z.-J. Hou, I. Gati and X. X. Li, "Effects of Parental Expectations and Cultural-Values Orientation on Career Decision-Making Difficulties of Chinese University Students," Journal of Vocational Behavior, Vol. 78, No. 1, 2011, pp. 11-20. doi:10.1016/j.jvb.2010.08.004
[26] S. Brown, A. Ortiz-Nunez and K. Taylor, "What Will I Be When I Grow Up? An Analysis of Childhood Expectations and Career Outcomes," Economics of Education Review, Vol. 30, No. 3, 2011, pp. 493-506.

doi:10.1016/j.econedurev.2010.12.003 